MATEC Web of Conferences 9, 02012 (2013)

DOI: $10.1051 /$ matecconf/20130902012

(C) Owned by the authors, published by EDP Sciences, 2013

\title{
Semi-natural test methods to evaluate fire safety of wall claddings
}

\author{
Miroslav Smolka, Birgitte Messerschmidt, John Scott and Bruce le Madec \\ Rockwool International A/S, Hedehusene, Denmark
}

\begin{abstract}
External walls and their components are subjected to a number of fire safety requirements. Fire resistance and reaction to fire are the harmonised requirements in the EU. These cover two fire scenarios: contribution of internal wall linings to an intermediate-size developing fire inside a fire compartment, and resistance of external walls to post-flashover fire inside a fire compartment (resistance to an external fire may also be required). The spread of fire along the external surface is not part of this European evaluation system and remains subjected to national fire safety codes and regulations. A number of test methods covering this scenario exist in Europe and North America at national levels as well as at the international level (ISO). These test methods and associated criteria differ in fire size, test duration, test specimen size and configuration. This paper presents principles of major existing test methods and comparison of test results on comparable test specimens where they are available.
\end{abstract}

\section{INTRODUCTION: IMPORTANCE OF FIRE SPREAD}

The Construction Products Regulation (CPR) [1] provides the regulatory framework for the performance of construction products in Europe. In the CPR, the Basic requirement for construction works no. 2 "Safety in case of fire" requires that the construction works must be designed and built in such a way that in the event of an outbreak of fire:

- the load-bearing capacity of the construction can be assumed for a specific period of time;

- the generation and spread of fire and smoke within the construction works are limited;

- the spread of fire to neighbouring construction works is limited;

- occupants can leave the construction works or be rescued by other means;

- the safety of rescue teams is taken into consideration.

External wall cladding may become a contributing factor in a fire incident in all these aspects!

Yet the practical way of evaluating the safety of external wall claddings in case of fire differs a lot from this definition - at least at the level of harmonised approach to construction products in EU. External wall claddings and their components are evaluated for reaction to fire as standalone products and assemblies to EN 13501-1 [2] in a room fire scenario; fire resistance requirements to EN 13501-2 [3] may comprise wall claddings as part of the structure; and spread of fire along the external surface is currently not part of this harmonised system at all. Consequently European member states, which presently regulate for this characteristic, have to rely on national test methods.

Therefore it is worthwhile to look at the approaches used in European Member States and overseas. The methods for evaluating the fire spread over external wall claddings are diverse although some similarities can be identified.

\section{LIMITS TO HARMONISATION}

\section{Reaction to fire: EN 13501-1 [2]}

Declaring the reaction to fire class of products as they are placed on the market is a basic requirement for any construction product. If these products are placed on the market as a kit, it may be required to

This is an Open Access article distributed under the terms of the Creative Commons Attribution License 2.0, which permits unrestricted use, distribution, and reproduction in any medium, provided the original work is properly cited. 


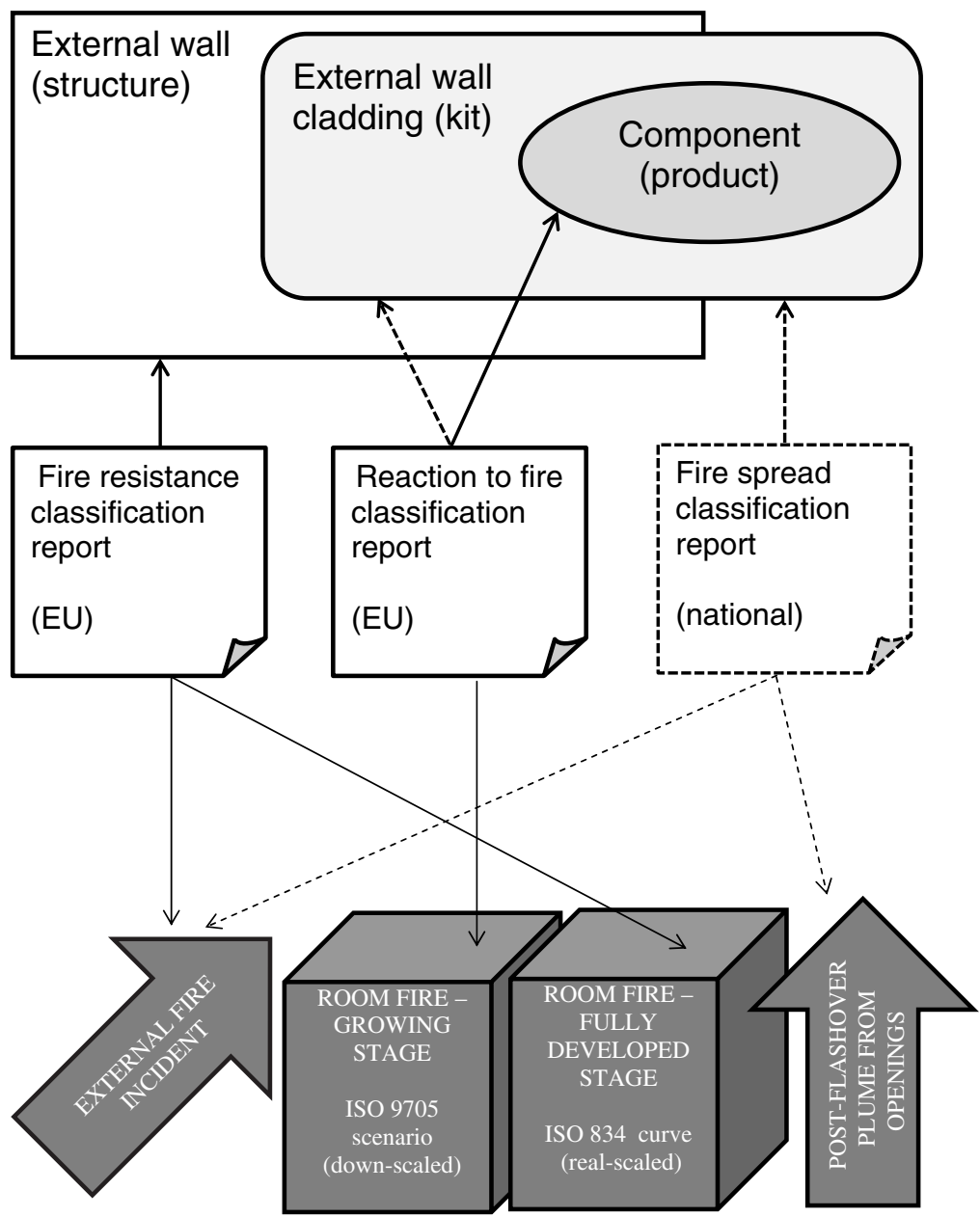

Figure 1. Fire safety characteristics in legal evaluation systems in EU. Although the spread of fire is an important part of the CPR [1] definition (BWR 2), it has not been harmonized. The picture also shows which fire scenarios are normally represented by classification reports. External wall may comprise the cladding system. Fire spread may be considered part of the national reaction to fire classification and/or represent a benchmark - not a real-scale testing in some Member States.

declare the class for the assembled kit. It is important to realise the purpose and assumptions of this information (Fig. 1).

Reaction to fire classification system in the $\mathrm{EU}$ is based on a scenario of internal room fire during the growing stage and ISO 9705 [4] alias EN 14390 [5] is the only available large-scale reference test. Classification reports to EN 13501-1 [2] for external wall cladding systems need to be seen from the perspective of this logic. The principal of the harmonised system is that the result from the SBI test [6] is correlated to that of the large-scale reference test.

Generation of smoke as part of the EN 13501-1 [2] criteria is solely based on the SBI [6] test exposure of $30,75 \mathrm{~kW}$. As the response of products (and especially laminated kits e.g. ETICS [7]) to a growing fire is not linear, this information is related to this level of fire exposure only.

Generation of droplets is another supplementary class contained in the EN 13501-1 [2] classification system. It is tested on products and kits installed vertically with fire source impinging on a flat side of 
the wall where no additional installation details are tested. Any combustible core components covered by a protective surface layer will normally not produce droplets in the SBI [6] test. For external wall cladding system however, important details like the fire-exposed vertical window edge and especially the bottom edge (lintel and system base) need to be tested; these details are not part of the test specimen. It is also here that a semi-natural fire test provides valuable information.

\section{Fire resistance: EN 13501-2 [3]}

External wall claddings may be considered to be part of the external wall assembly, as far as fire resistance of external wall is considered. This is especially important in drywall systems like timberframe; it is with these types of external walls that the external cladding may have an impact on loadbearing capacity of the external wall.

For typical masonry and concrete external walls, fire resistance of the loadbearing part of the wall is more than sufficient to meet standard fire resistance criteria. The presence of a combustible or noncombustible external cladding system does not impact the loadbearing capacity of the original wall to a significant degree.

\section{External fire spread}

Although mentioned several times in the CPR definition of the Basic work requirement "Fire safety", spread of fire along the external wall surface has not become part of the European legal system for evaluating construction products' fire safety. For some reason, it is part of the evaluation of roof coverings and roof assemblies, however. EN 13501-5 [8] is hopefully a unique example of failed harmonisation process where one classification standard referring to a CEN/TS document [9] containing 4 different test methods results in 4 different classification criteria.

\section{EXTERNAL FIRE SPREAD FROM INTERNATIONAL PERSPECTIVE}

In the absence of harmonisation, safety against fire spreading along external is handled by individual Member States - differently almost in each of them. Fire spread tests are not part of regulatory systems everywhere; and where they are present, they may serve as supplementary information to other approaches, like calculation of calorific potential of wall claddings, normative requirements on structural details, safe distances, provisions against falling droplets, etc.

The variety of approaches, differences, and similarities is illustrated by the list of major test methods shown in Tables 1 and 2.

\section{European test methods}

In the absence of harmonised approach, 1/3 of EU countries use their own methods for defining safety levels of fire spread on external walls. As shown below, these safety levels differ. Apart from the Polish standard, all the test methods simulate a fire attack on the wall external face in a post-flashover window fire plume scenario, and are used as an alternative route to prove an equal level of safety to the one defined by prescriptive requirements. More than test configuration, the use of test results is defined by safety criteria which are quite different.

\section{International test methods}

A large-scale test method has been developed by ISO, but this is not used for approvals in any country. A couple of diverse methods are in use in North America, and one method exists in Russia and some other former USSR countries. 


\section{MATEC Web of Conferences}

Table 1. Main parameters of major international and national test methods for fire spread on external wall cladding. European tests.

\begin{tabular}{|c|c|c|c|c|c|c|c|}
\hline Standard & BS 8414-1 & LEPIR II & $\begin{array}{l}\text { MSZ } \\
14800-6\end{array}$ & $\begin{array}{ll}\text { SP } & \text { FIRE } \\
105 & \\
\end{array}$ & $\begin{array}{l}\text { Önorm B } \\
3800-5\end{array}$ & $\begin{array}{ll}\text { DIN } \\
4102-20\end{array}$ & $\begin{array}{l}\text { PN-90/B- } \\
02867\end{array}$ \\
\hline Country & UK & $\mathrm{F}$ & $\mathrm{H}$ & $\mathrm{S}$ & $\mathrm{A}$ & $\mathrm{D}$ & PL \\
\hline $\begin{array}{l}\text { Fire } \\
\text { exposure }\end{array}$ & $\begin{array}{l}\text { Wood crib, } \\
\text { peak heat } \\
3,5 \mathrm{MW} \text {, } \\
4500 \mathrm{MJ}\end{array}$ & $\begin{array}{l}600 \mathrm{~kg} \\
\text { wood crib }\end{array}$ & $\begin{array}{l}380 \mathrm{~kg} \\
\text { wood } \\
\text { crib/10 kg } \\
\text { Diesel oil }\end{array}$ & $\begin{array}{l}601 \\
\text { heptane }\end{array}$ & $\begin{array}{l}25 \mathrm{~kg} \\
\text { wood / } \\
320 \mathrm{~kW} \\
\text { propane }\end{array}$ & $\begin{array}{l}25 \mathrm{~kg} \\
\text { wood / } \\
320 \mathrm{~kW} \\
\text { propane }\end{array}$ & $\begin{array}{l}20 \mathrm{~kg} \text { wood } \\
\text { crib + wind } \\
\text { towards the } \\
\text { wall }(2 \mathrm{~m} / \mathrm{s})\end{array}$ \\
\hline $\begin{array}{l}\text { Max. heat } \\
\text { flux on } \\
\text { surface }\end{array}$ & $\begin{array}{l}70 \mathrm{~kW} / \mathrm{m}^{2} \text { at } \\
1 \mathrm{~m} \text { height }\end{array}$ & $\begin{array}{l}\text { Not } \\
\text { specified }\end{array}$ & $\begin{array}{l}\text { Not } \\
\text { specified }\end{array}$ & $\begin{array}{l}15 \text { or } \\
80 \mathrm{~kW} / \mathrm{m}^{2}\end{array}$ & $\begin{array}{l}\text { Not } \\
\text { specified }\end{array}$ & $\begin{array}{l}70- \\
95 \mathrm{~kW} / \mathrm{m}^{2} \\
\text { at } 1 \mathrm{~m} \\
\text { height }\end{array}$ & Not specified \\
\hline $\begin{array}{l}\text { Max. tem- } \\
\text { perature } \\
\text { on surface }\end{array}$ & $\begin{array}{l}600^{\circ} \mathrm{C} / \\
20 \mathrm{~min}\end{array}$ & $\begin{array}{l}\text { Average } \\
500^{\circ} \mathrm{C}, \\
\text { peak } \\
800^{\circ} \mathrm{C}\end{array}$ & $\begin{array}{l}600^{\circ} \mathrm{C} \\
0,5 \mathrm{~m} \text { high } \\
/ 50 \mathrm{~min}\end{array}$ & $\begin{array}{l}450^{\circ} \mathrm{C} / \\
12 \mathrm{~min}\end{array}$ & $\begin{array}{l}\text { Not } \\
\text { specified }\end{array}$ & $\begin{array}{l}\text { Not } \\
\text { specified }\end{array}$ & $800^{\circ} \mathrm{C}$ peak \\
\hline $\begin{array}{l}\text { Test } \\
\text { duration }\end{array}$ & $30 \mathrm{~min}$ & $\begin{array}{l}\text { Min. } \\
30 \text { min }\end{array}$ & $40 \mathrm{~min}$ & $\begin{array}{l}\text { Min. } \\
12 \mathrm{~min}\end{array}$ & $30 \mathrm{~min}$ & $\begin{array}{l}21 \mathrm{~min} \\
\text { gas, } \\
30 \mathrm{~min} \\
\text { wood }\end{array}$ & $30 \mathrm{~min}$ \\
\hline $\begin{array}{l}\text { Test } \\
\text { specimen }\end{array}$ & $\begin{array}{l}\text { Corner } \\
2,5 \mathrm{~m} \times \\
8,0 \mathrm{~m}+ \\
1,5 \mathrm{~m} \times \\
8,0 \mathrm{~m}\end{array}$ & $\begin{array}{l}\text { Flat wall } \\
3,0 \mathrm{~m} \times \\
5,5 \mathrm{~m}\end{array}$ & $\begin{array}{l}\text { Flat wall } \\
6,0 \mathrm{~m} \times \\
7,0 \mathrm{~m}\end{array}$ & $\begin{array}{l}\text { Flat wall } \\
4,0 \mathrm{~m} \times \\
6,7 \mathrm{~m}\end{array}$ & $\begin{array}{l}\text { Corner } \\
3,0 \mathrm{~m} \times \\
6,0 \mathrm{~m}+ \\
1,5 \mathrm{~m} \times \\
6,0 \mathrm{~m}\end{array}$ & $\begin{array}{l}\text { Corner } \\
3,0 \mathrm{~m} \times \\
5,2 \mathrm{~m}+ \\
2,0 \mathrm{~m} \times \\
5,2 \mathrm{~m}\end{array}$ & $\begin{array}{l}\text { Flat wall } \\
2,3 \mathrm{~m} \text { high }\end{array}$ \\
\hline Substrate & $\begin{array}{l}\text { Masonry or } \\
\text { light frame }\end{array}$ & Any & Masonry & $\begin{array}{l}\text { Aerated } \\
\text { concrete }\end{array}$ & $\begin{array}{l}\text { Aerated } \\
\text { concrete }\end{array}$ & $\begin{array}{l}\text { Aerated } \\
\text { concrete }\end{array}$ & Masonry \\
\hline Criteria $^{a}$ & Temp. limits & $\begin{array}{l}\text { Flame on } \\
2^{\text {nd }} \text { floor }\end{array}$ & $\begin{array}{l}\text { Temp. rise, } \\
\text { fire spread, } \\
\text { falling } \\
\text { parts }^{\mathrm{b}}\end{array}$ & $\begin{array}{l}\text { Flames } 2 \\
\text { floors } \\
\text { above; } \\
\text { Falling } \\
\text { parts }\end{array}$ & $\begin{array}{l}\text { Temp. rise, } \\
\text { fire spread, } \\
\text { falling } \\
\text { parts }^{\mathrm{b}}\end{array}$ & $\begin{array}{l}\text { Temp. rise, } \\
\text { fire spread, } \\
\text { falling } \\
\text { parts }^{\mathrm{b}}\end{array}$ & $\begin{array}{l}\text { Temp. } \\
\text { limits; } \\
\text { Burning } \\
\text { particles }\end{array}$ \\
\hline
\end{tabular}

A few notes on the existing European and international test methods:

BS 8414-1 [10]: A real-size test to simulate post-flashover plume from an opening in external wall. Passing this test results in unlimited application of the external wall cladding product. Different criteria exist in basic regulation [11] and in insurance approval schemes [12, 13].

LEPIR II [14]: This test is not part of French regulatory requirement; it is used for development purposes. No approval criteria are linked to this method in French regulations.

MSZ 14800-6 [15]: A real-sized approval test originated from LEPIR. A revision is on-going; adding a lateral wing to the flat wall is under consideration.

SP FIRE 105 [16]: A draft method used as an alternative route for approval in Sweden, and for research and development purposes. Under consideration in Denmark and Norway.

DIN E 4102-20 [17]: A benchmark draft test method used for national approval of external wall cladding systems for mid-height buildings. This test does not represent an external fire attack other than the window-plume situation.

Önorm B 3800-5 [18]: A variation of the draft DIN method that can be used for product approvals in Austria.

ISO 13785-2[19]: A real-scale test representing both a post-flashover window plume scenario, and an external fire attack. Similar in nature to the BS 8414-1 [10] test. 
$1^{\text {st }}$ International Seminar for Fire Safety of Facades, Paris (France), 2013

Table 2. Main parameters of major international and national test methods for fire spread on external wall cladding. International and overseas tests.

\begin{tabular}{|c|c|c|c|c|c|c|c|}
\hline Standard & $\begin{array}{l}\text { ISO } \\
13785-2\end{array}$ & $\begin{array}{l}\text { ISO } \\
\text { 13785-1 }\end{array}$ & GOST 31251 & NFPA 285 & NFPA 268 & $\begin{array}{l}\text { CAN/ULC- } \\
\text { S134 }\end{array}$ & $\begin{array}{l}\text { CAN/ULC- } \\
\text { S101 + } \\
\text { CAN/ULC- } \\
\text { S114 }\end{array}$ \\
\hline Country & none & $\mathrm{CZ}$ & $\begin{array}{l}\text { AZ, AM, KG, } \\
\text { KZ, MD, RU, } \\
\text { TJ, UZ, UA }\end{array}$ & USA & USA & $\mathrm{CAN}$ & $\mathrm{CAN}$ \\
\hline $\begin{array}{l}\text { Fire } \\
\text { exposure }\end{array}$ & $\begin{array}{l}\text { Propane } \\
\text { set by } \\
\text { calibration }\end{array}$ & $\begin{array}{l}\text { Propane } \\
100 \mathrm{~kW}\end{array}$ & $\begin{array}{l}\text { Soft wood } \\
700 \mathrm{MJ} / \mathrm{m}^{2}\end{array}$ & Gas burner & $\begin{array}{l}\text { Radiant } \\
\text { panel } \\
12,5 \mathrm{~kW} / \mathrm{m}^{2}\end{array}$ & $\begin{array}{l}\text { Propane } \\
\text { set by } \\
\text { calibration }\end{array}$ & $\begin{array}{l}\text { Defined } \\
\text { time/temp } \\
\text { curve }\end{array}$ \\
\hline $\begin{array}{l}\text { Max. heat } \\
\text { flux on } \\
\text { surface }\end{array}$ & $\begin{array}{l}55 \mathrm{~kW} / \mathrm{m}^{2} \\
\text { at } 0,6 \mathrm{~m} \\
\text { height }\end{array}$ & $\begin{array}{l}\text { Not } \\
\text { specified }\end{array}$ & $\begin{array}{l}12,5 \mathrm{~kW} / \mathrm{m}^{2} \text { at } \\
2 \mathrm{~m} \text { height }\end{array}$ & $\begin{array}{l}38- \\
40 \mathrm{~kW} / \mathrm{m}^{2} \\
\text { at } \\
0,6-1,2 \mathrm{~m} \\
\text { height }\end{array}$ & $12,5 \mathrm{~kW} / \mathrm{m}^{2}$ & $\begin{array}{l}45 \mathrm{~kW} / \mathrm{m}^{2} \\
\text { at } 0,5 \mathrm{~m} \\
\text { height }\end{array}$ & $\begin{array}{l}\text { Not } \\
\text { specified }\end{array}$ \\
\hline $\begin{array}{l}\text { Max. tem- } \\
\text { perature } \\
\text { on surface }\end{array}$ & $\begin{array}{l}\text { Min. } \\
800^{\circ} \mathrm{C}\end{array}$ & $\begin{array}{l}\text { Max. } \\
150^{\circ} \mathrm{C} \text { at } \\
0,5 \mathrm{~m} \\
\text { height }\end{array}$ & $\begin{array}{l}750^{\circ} \mathrm{C} \text { at } \\
\text { lintel }\end{array}$ & $\begin{array}{l}712{ }^{\circ} \mathrm{C} \text { at } \\
0,9 \mathrm{~m} \\
\text { height }\end{array}$ & $\begin{array}{l}\text { Not } \\
\text { specified }\end{array}$ & $\begin{array}{l}\text { Approx. } \\
415^{\circ} \mathrm{C}\end{array}$ & $\begin{array}{l}\text { Not } \\
\text { specified }\end{array}$ \\
\hline $\begin{array}{l}\text { Test } \\
\text { duration }\end{array}$ & $23-27 \mathrm{~min}$ & $30 \mathrm{~min}$ & $35 \mathrm{~min}$ & $30+10 \mathrm{~min}$ & $20 \mathrm{~min}$ & $25 \mathrm{~min}$ & $\begin{array}{l}\text { Min. } \\
15 \mathrm{~min}\end{array}$ \\
\hline $\begin{array}{l}\text { Test } \\
\text { specimen }\end{array}$ & $\begin{array}{l}\text { Corner } \\
3,0 \mathrm{~m} \times \\
5,7 \mathrm{~m}+ \\
1,2 \mathrm{~m} \times \\
5,7 \mathrm{~m}\end{array}$ & $\begin{array}{l}\text { Corner } \\
1,2 \mathrm{~m} \times \\
2,4 \mathrm{~m}+ \\
0,6 \mathrm{~m} \times \\
2,4 \mathrm{~m}\end{array}$ & $\begin{array}{l}\text { Flat wall } \\
3,0 \mathrm{~m} \times 5,1 \mathrm{~m}\end{array}$ & $\begin{array}{l}\text { Flat wall } \\
4,1 \mathrm{~m} \times \\
5,3 \mathrm{~m}\end{array}$ & $\begin{array}{l}\text { Flat wall } \\
1,2 \mathrm{~m} \times \\
2,4 \mathrm{~m}\end{array}$ & $\begin{array}{l}\text { Flat wall } \\
10 \mathrm{~m} \text { high }\end{array}$ & $\begin{array}{l}\text { Flat } \\
\text { wall min. } \\
2,8 \mathrm{~m} \times \\
2,8 \mathrm{~m}\end{array}$ \\
\hline Substrate & Any & $\begin{array}{l}12 \mathrm{~mm} \\
\mathrm{Ca}-\mathrm{Si} \\
\text { board }\end{array}$ & $\begin{array}{l}\text { Masonry } \\
\text { concrete }\end{array}$ & $\begin{array}{l}150 \mathrm{~mm} \text { th. } \\
\text { floor slabs }\end{array}$ & Steel tube & Concrete & None \\
\hline Criteria $^{\mathrm{a}}$ & $\begin{array}{l}\text { Not } \\
\text { included }\end{array}$ & $\begin{array}{l}\text { Not } \\
\text { included }\end{array}$ & Not included & $\begin{array}{l}\text { Flame } \\
\text { spread, } \\
\text { temp. rise }\end{array}$ & Ignition & $\begin{array}{l}\text { Vertical } \\
\text { flame } \\
\text { spread, } \\
\text { heat flux }\end{array}$ & $\begin{array}{l}\text { Integrity of } \\
\text { top layerc }\end{array}$ \\
\hline
\end{tabular}

a) Additional criteria may be contained in other standards or regulations.

b) Temperature rise, vertical and horizontal flame spread.

c) Protection of foam plastics on external facade - protective layer must remain in place, no openings developed, does not disintegrate. S114 is additional non-combustibility requirement.

ISO 13785-1 [20]: A screening method for ISO 13785-2 [16]. Despite the limitation in its scope, the test is currently used in Czech Republic as an alternative route for product approvals.

GOST 31251 [21]: A semi-natural test similar to the MSZ14800-6 [15] method. Similarly, the application of test results is linked to classes depending on measured values.

NFPA 285 [22]: A benchmark test comprising 2 burners: one in the combustion chamber, and an additional one simulating a fire attack on the lintel.

NFPA 268 [23]: A radiant panel test used to determine ignition resistance of claddings i.e. another building on fire.

CAN/ULC-S134 [24]: A real-scale semi-natural test similar to BS 8414-1 [10] but not containing a lateral wing.

CAN/ULC-S101 [25] + CAN/ULC-S114 [26]: A combination of a fire resistance and combustibility tests applied specifically to protection of foamed plastics. 
MATEC Web of Conferences

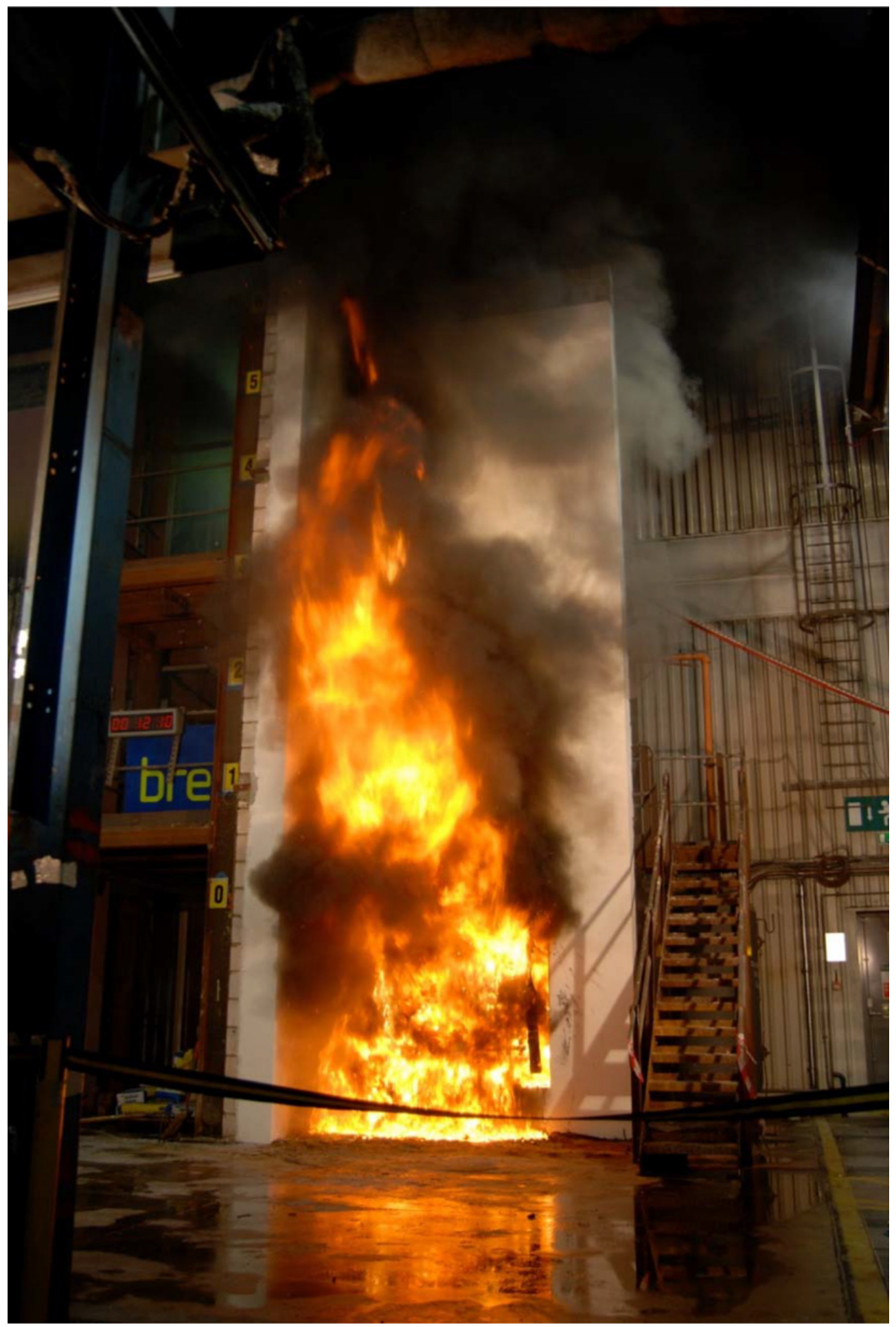

Figure 2. ETICS system with organic rendering containing $200 \mathrm{~mm}$ high fire-stopping strip made of stone wool installed within EPS insulation layer, tested in ISO BS 8414-1 [10] configuration (3 MW heat source). 


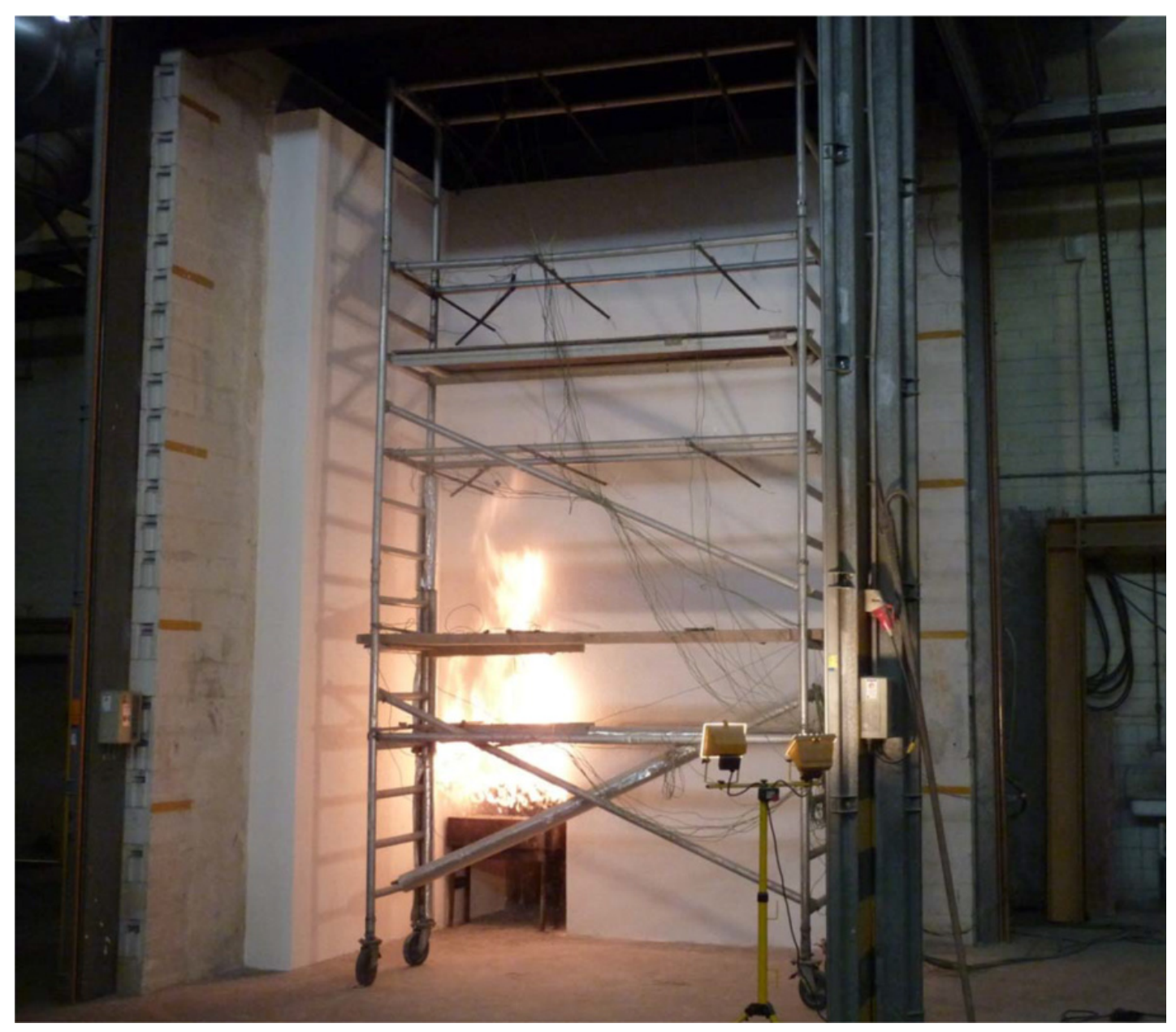

Figure 3. ETICS system with organic rendering containing $200 \mathrm{~mm}$ high fire-stopping strip made of stone wool installed within EPS insulation layer, tested in DIN E 4102-20 [17] configuration (320 kW heat source).

\section{TEST RESULTS FOR COMPARISON OF TEST METHODS}

Although some of the methods depicted above show certain similarities, the diversity of measured values and evaluation criteria make it impossible to provide correlation between various test methods. Any test programmes providing data for comparison are of high value.

An example of a project of this type has been carried out recently by and results are publicly available $[27,28]$. These results point to some interesting conclusions:

- The test specimens were ETICS systems with different types of renders and combinations of insulating core made of expanded polystyrene with stone wool fire-stopping strips of various sizes included at different positions relative to the lintel. Response of this type of laminated kit containing non-homogeneous insulation core to fire differs not only in relation to the fire size, but also to different types of render materials.

- The fire-stopping strips made of stone wool proved effective in some test configurations and specimen types, while ineffective in others. 


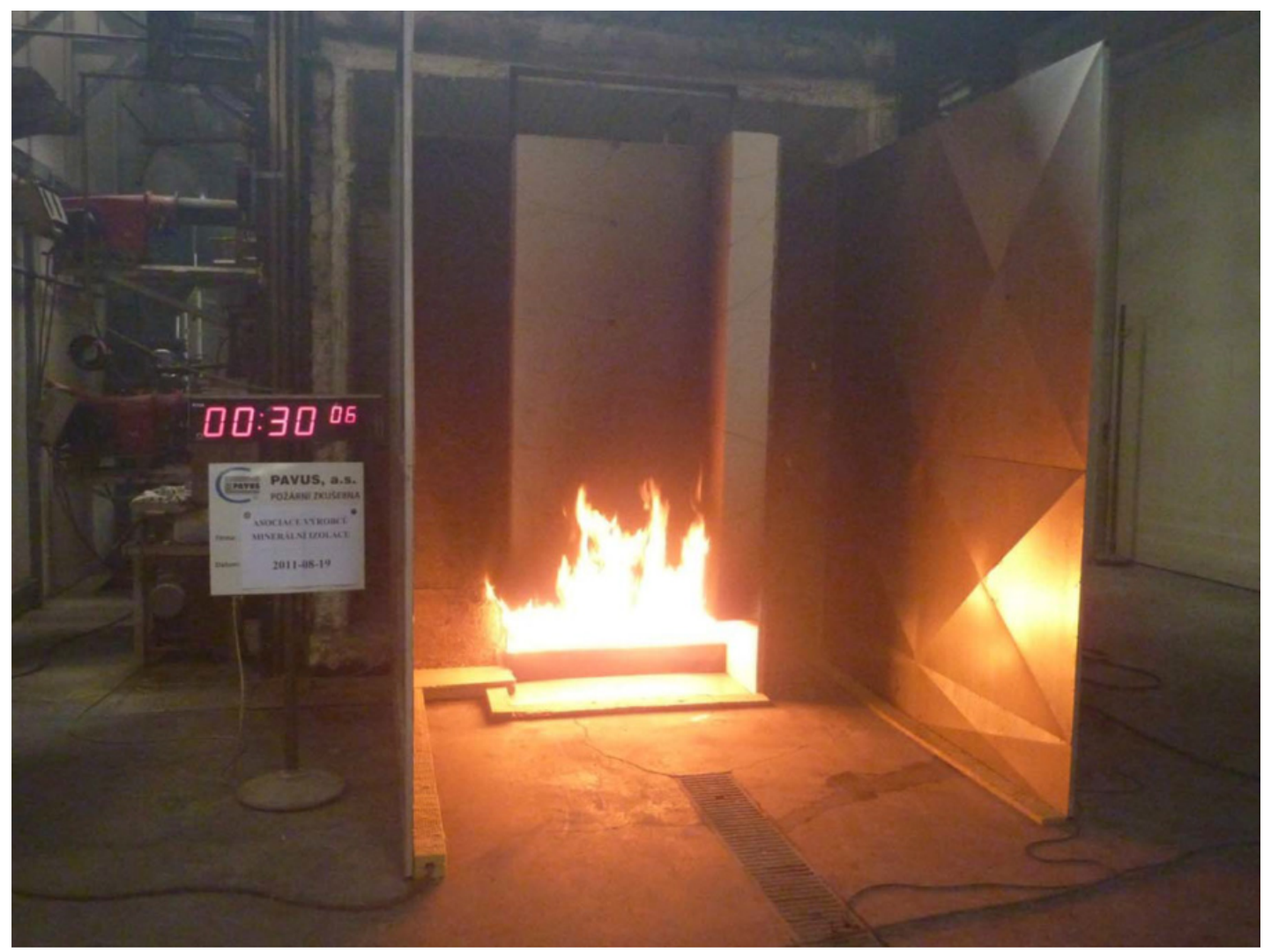

Figure 4. ETICS system with organic rendering containing $200 \mathrm{~mm}$ high fire-stopping strip made of stone wool installed within EPS insulation layer, tested in ISO 13785-1 [20] configuration (100 kW heat source).

Comparison of test results [27] have been done based on different pass/fail criteria linked to each standard. However, no correlations between the tests were possible regarding burning behaviour of the tested kits, measured temperatures, or heat flux.

The response of an almost identical specimen to different fire sources varied, and is shown on figures 2 to 4: $100 \mathrm{~kW}$ propane burner of ISO 13785-1 [20] (Fig. 2); $320 \mathrm{~kW}$ propane burner of DIN E 4102-20 [17] (Fig. 3); and 3 MW output from a timber crib of BS 8414-1 [10] (Fig. 4).

\section{CONCLUSION}

It is not only different test methods used worldwide, but also principally different criteria linked to these methods that result in different external wall cladding kits being approved to be safe in one region but maybe not in another. Despite that fire spread is an integral part of the CPR [1] definition of the basic work requirement "Safety in case of fire", this product characteristic is not part of existing mandates from the Commission or published European Technical Approval Guidelines. In Europe, evaluation of safety of external wall cladding kits is still based on reaction to fire, which is inadequate. Existing declarations used for CE-marking provide a very elementary safety net and a benchmark - not relevant information to evaluate safety against fire spread.

As the example of roofing products show, creating European standards just by collecting mutually incompatible different test methods is not a route for real harmonisation. The purpose of CE-marking 
is to provide a relevant product characteristics linked to the CPR [1] definitions that can be used by member states to define safety levels as they find appropriate, based on proper understanding of product performance and real risks.

\section{References}

[1] Regulation (EU) No. 305/2011 of the European Parliament and of the Council of 9 March 2011 laying down harmonised conditions for the marketing of construction products and repealing Council Directive 89/106/EEC

[2] EN 13501-1 Fire classification of construction products and building elements -part 1: Classification using test data from reaction to fire tests. CEN 2002

[3] EN 13501-2 Fire classification of construction products and building elements -part 2: Classification using data from fire resistance tests, excluding ventilation services. CEN, 2007

[4] ISO 9705 Fire Tests-Full-scale Room Test for Surface Products. ISO, 1993

[5] EN 14390 Fire test - Large-scale room reference test for surface products. CEN, 2007

[6] EN 13823, Reaction to fire tests for building products - Building products excluding floorings exposed to the thermal attack by a single burning item. CEN, 2002

[7] ETAG 004. Guideline for European Technical Approval of External Thermal Insulation Composite Systems (ETICS). EOTA 2008.

[8] EN 13501-5 Fire classification of construction products and building elements -part 5: Classification using data from external fire exposure to roofs tests. CEN, 2005.

[9] CEN/TS 1187 Test methods for external fire exposure to roofs. CEN, 2012

[10] BS 8414-1 Fire performance of external cladding systems. Test methods for non-loadbearing external cladding systems applied to the face of a building. BSI, 2002

[11] BR 135, Fire performance of external thermal insulation for walls of multi-storey buildings, second edition, 2003, BRE report

[12] LPS 158: Issue 2.0:2010, Requirements and tests for LPCB approval of non-loadbearing external cladding systems applied to the masonry face of a building

[13] LPS 158: Issue 1.0:2010, Requirements and tests for LPCB approval of non-loadbearing external cladding systems fixed to and supported by a structural steel frame

[14] LEPIR II. test method for fire spread. 1970

[15] MSZ 14800-6 Fire resistance tests. Part 6: Fire propagation test for building facades. Hungarian standardisation institute 2009.

[16] SP FIRE 105. Issue 5. Large scale testing of facade systems. SP Boras Sweden, 1994

[17] DIN E 4102-20 (draft) Brandverhalten von Baustoffen und Bauteilen, Teil 20: Besonderer Nachweis für das Brandverhalten von Außenwandbekleidungen. DIN 2009

[18] Önorm B 3800-5 (draft) Fire behaviour of building materials and components - Part 5: Fire behaviour of facades - Requirements, tests and evaluations. Austrian Standards Institute, 2003

[19] ISO 13785-2 Reaction-to-fire tests for façades -Part 2: Large-scale test. ISO, 2002

[20] ISO 13785-1 Reaction-to-fire tests for façades -Part 2: Intermediate-scale test. ISO, 2002

[21] GOST 31251-2008. Facades of buildings. Fire hazard test method. Interstate council for standardisation, metrology and certification 2010

[22] NFPA 285. Standard Fire Test Method for Evaluation of Fire Propagation Characteristics of Exterior Non-Load-Bearing Wall Assemblies Containing Combustible Components. NFPA, 2012

[23] NFPA 268. Standard Test Method for Determining Ignitibility of Exterior Wall Assemblies Using a Radiant Heat Energy Source. NFPA, 2012

[24] CAN/ULC-S134. Standard Method of Fire Test of Exterior Wall Assemblies. Underwriters Laboratories of Canada, 2013 


\section{MATEC Web of Conferences}

[25] CAN/ULC-S101 Standard Methods of Fire Endurance Tests of Building Construction and Materials. Underwriters Laboratories of Canada, 2007

[26] CAN/ULC-S114. Standard Method of Test for Determination of Non-Combustibility in Building Materials. Underwriters Laboratories of Canada, 2005

[27] “A comparison of BS 8414-1 \& -2, draft DIN 4102-20, ISO 13785-1 \& -2, EN 13823 and EN ISO 11925-2.” Report number CC275194 issue 2. BRE Global Ltd. 2012

[28] Messerschmidt, B., Fellman, J.: "Fire Testing of ETICS a comparative study". Proceedings of International Conference Interflam 2013, Windsor, UK. Interscience Communications 2013. 